\title{
Carbon C-13 Dextromethorphan
}

National Cancer Institute

\section{Source}

National Cancer Institute. Carbon C-13 Dextromethorphan. NCI Thesaurus. Code C95199.

A radioconjug ate consisting of dextromethorphan, a synthetic, methylated dextrorotatory analogue of levorphanol, conjug ated with carbon-13 [(13)C] with radiotracer activity. (13)C-dextromethorphan can be used in a breath-test phenotype assay of CYP2D6 activity, based on the principle that CYP2D6-mediated O-demethylation cleaves a (13) $\mathrm{CH} 3$ that enters the body's carbon pool to be eliminated ultimately as (13)CO2 in expired air, which can be measured. The (13)C-dextromethorphan breath test may prove useful in identifying poor CYP2D6 metabolizers of such important clinical drugs as tamoxifen. 